\title{
Socio-Economic Impact of Nigerian Brewery Industry in Kaduna South Local Government Area of Kaduna State, Nigeria
}

\author{
Ali, Alphonsus Nwachukwu \\ Department Geography, University of Nigeria, Nsukka; alphonsusnwachukwu@yahoo.com \\ Iwuchukwu, Christian Uche \\ Department of Geography, University of Nigeria, Nsukka
}

\section{Doi:10.5901/mjss.2015.v6n6s4p59}

\begin{abstract}
This study examined the socio-economic impact of Nigerian Brewery Company on the Kaduna South Local Government Area. To achieve this, a survey was carried out between January and July, 2014. In 7 sample districts purposively and randomly selected for this study, 140 households were randomly selected to elicit their perceptions of socio-economic impact of Nigerian Brewery Company on Kaduna South Local Government Area, using self-rated questionnaire. Data collected were analysed using descriptive statistics and Principal Component analysis (PCA). The results of these analyses depicted the positive and negative impacts of the Nigerian Brewery Company on Kaduna South LGA. Using Principal Component Analysis (PCA), 9 social impact variables of the company were reduced to two major components (provision of social facilities and insecurity) impacting on the area. These two major components together explained $94.97 \%$ of the cumulative variance of our PCA. On the other hand, 9 economic impact variables were also reduced to three major components ( increase in standard of living, high cost of living and increase in commercial activities, and increase in income generation) impacting on the area. These three major components of economic impact on the area, together explained $95.53 \%$ of the cumulative variance of our PCA. Based on our findings, recommendations were made on how to improve the socio-economic conditions of the people of the area by the shareholders of the Nigerian Brewery.
\end{abstract}

Keywords: Nigerian Brewery, socio-economic, impact, Kaduna South, Households.

\section{Introduction}

Industrial development on the earth surface is a major source of growth, especially since the industrial revolution of the 18th century in England (Banii 2000). The brewing industry has constituted a major focus of interest in industrial organisation economics since the 2nd world war (Scherer, 2000). The pattern of growth in brewery industry dates back to $1200 \mathrm{AD}$, when the German brewery was established and it brought about a formal system of manufacturing which boosted the emergence of Europe as a strong growth pole (Room, 2000)

A brewery is a dedicated building for the making of beer, though beer can be made at home, and has been for much of beer's history. Thus, a company or industry that makes beer is called either a brewery or a brewery industry. The diversity of size in breweries is matched by the diversity of processes, degrees of automation, and kinds of beer produced in breweries. Generally, world beer production has been on upward trend with minimum annual growth rate of $1.3 \%$ from 2000-2003. The growth of beer production has been remarkable in Asia, Europe and America. But in Africa and Australia, production growth rate has remained at less than $1 \%$. Europe is the world's leading region in beer production with a growth rate of $1.5 \%$ from 2000-2003, followed by the USA, Asia, Africa and Australia (Babor, 2008)

The brewery industries in Nigeria are one of the flagship consumer sectors and have rightly become a priority holding for many investors in the Nigerian Stock Market (Furnivall, 2009). Nigerian Breweries was incorporated in 1946 and currently operates 5 breweries namely Lagos, Aba, Kaduna, Ibadan and Ama. Nigerian Breweries brew, bottles and distributes beer and malt drinks. The brewery industry is one of the fastest growing branches of Nigerian manufacturing sector. It contributes about 28\% of Manufactured Added Value (MAV) and provides direct employment for over 50,000 persons. The indirect employment associated with the industry is close to nearly 500,000 including the firms producing ancillary services (Wole, 2009). Orekoya (2009) states that there were about 32 breweries in 1991 producing more than 40 beer brands based on an equity research on brewery industries in Nigeria. Production grew rapidly from 1980-1982, being the fastest branch of the manufacturing sector in Nigeria. The volume of production was five times greater than 
earlier production in 1970. In 1982-1986 when most branches experienced severe difficulties, production fell marginally during 1987 and 1988 due to restrictions on the import of barley malt and problems associated with the use of locally produced substitutes.

Over the past twenty years, Nigeria has experienced rapid rural-urban migration leading to tremendous urban growth. This growth in population has given rise to environmental degradation, which now characterized most of our towns and cities (Okpala 1999). Thus, it can be equally traced to the presence of industrialization.

The growth of economic activities like manufacturing, commerce etc and the provision of social amenities such as good roads, transportation network, potable water etc, have brought the tendency to transform a city from its natural environmental state to an artificial state (Best 2001). The establishment of a manufacturing industry improves the livelihood of the area where it is located through its employment opportunities and growth/multiplier effect tendencies (llori et al 2002).

The operation of any industry is obvious to bring about certain environmental (physical, social and economic) impact within its situated place. As such, it is also an accelerator of urban growth. A development/project may increase employment in the community and create demand for affordable housing. Both effects are easily quantifiable (Freeman et al 2003). However, the need to ascertain the environmental impact of a manufacturing industry such as the Nigerian Brewery PIc in Kaduna South Local Government Area is inevitable. This is because with the presence of the Nigerian brewery Plc in the area, there will definitely be a change in the social and economic aspect of the community both negatively and positively. Suleiman (2004), states that the waste water effluent discharged from the drains of the Nigerian Brewery Plc Kaduna to the environment poses less significant threat having been treated prior to its discharge. Odo (2010), states in his work that the effect of the chemical components of wastewater effluents of NB Plc Kaduna can possibly pose certain threats in creating faults on cement walls and blocks and thus can create cracks on constructed drainage where such effluents passes through. The environmental impact of Nigerian Brewery Plc Kaduna cannot be over stressed in its contribution towards the degradation of the community as seen in Kakuri, of Kaduna State (Okoye, 2008). The socio-economic changes occurring during the establishment and subsequent years of the development of the Nigerian Brewery Plc in Kaduna South Local Government Area of Kaduna State which must have had certain impacts on the lives of the people in the area have largely remained undocumented. To understand the positive and negative levels of socio-economic impacts of the development of the Nigeria Brewery PIc on the people of the Kaduna South Local Government Area, and make suggestions for future improvements, it is important to elicit insights from the people living in the area where the brewery is located of the changes they would like to see to get their expected socio-economic services from the brewery. This is because the responsibilities of the brewery to provide socio-economic services to the hosting LGA, is people-centred. By identifying the key dimensions that offer value and influence people's satisfaction with the socio-economic impacts of the brewery, appropriate strategies can be devised by the company to better deliver its socio-economic services to the people of the LGA. Thus, the aim of this study was to identify the key factors that determine the service quality attributes of the Nigerian Brewery PIc in Kaduna Local Government Area that explained the people's levels of satisfaction with the brewery's socio-economic services to the area so as to determine the quality of services for improvement.

\section{The Study Area}

Kaduna South Local Government Area is situated in the North-Central part of Kaduna State (Fig 1). Its geographical coordinates are latitude $10^{\circ} 27^{\prime} 43^{\prime \prime} \mathrm{N}$ and longitude $7^{\circ} 25^{\prime} 38^{\prime \prime} \mathrm{E}$. It is bounded in the North and North-East by Kaduna North LGA, in the North-West by Igabi LGA, in the South by Chikun LGA.Its headquarters is in the town of Makera. Kaduna South Local Government Area of Kaduna State have a population of 402,390 people as at 2006 census and have an area $59 \mathrm{~km}^{2}$.According to the koppen's classification of climate, Kaduna South LGA belongs to Aw which is marked by distinct wet and dry season. It has high temperature all year round. The mean daily temperature in the area can be as high as $34^{\circ} \mathrm{C}$ between months of March and May. Temperature could be as low as $20^{\circ} \mathrm{C}$ during the December to January. This low temperature is intensified by humidity due to the dry harmattan wind (Aboh, 2009). 


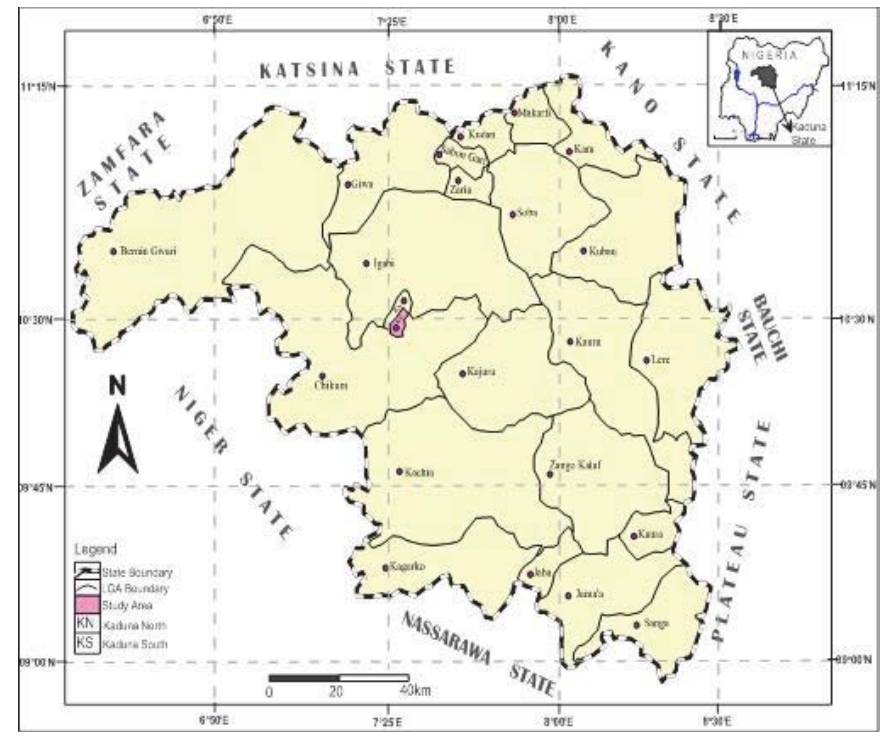

Figure 1: Map of Kaduna State Showing Kaduna South L.G.A. Source: Ministry of Land and Survey, Kaduna State.

\section{Research Methodology}

\subsection{Sampling and Data Collection}

Data were collected by the use of a questionnaire, field observations and oral interviews between March and June 2015. The questionnaire used in the study was based on published studies reviewed for this work, as well as in-depth interviews and extensive brainstorming. Kaduna South Local Government Area(LGA) households were the target population in this study. Their judgments were mainly sought because they would be best able to assess the levels of socio-economic impacts of the Nigerian Brewery PIc on the LGA and their satisfaction with such impacts. Seven sample districts of Makera, Kakuri, Nassarawa, Trikania, Kudenda, Barnawa, and Narayi from the twelve districts that make up the LGA were selected( Fig.2). This sample selection method adopted was purposeful sampling. Purposeful sampling was used to select districts spatially within the LGA that are having impacts of Nigerian Brewery Plc. In each of the sample districts a random sample size of twenty households were surveyed for this study. Therefore, for the seven sample districts, a total number of 140 household were used for the research. The methods adopted for data collection for this research work was the checklist. The choice of the checklist was due to its comprehensiveness and the potential of the method to suggest specific measurable indicators (UNEP, 1995). The checklists were used to collect data on social and economic impacts of the Nigerian Brewery PIc in the study area. 


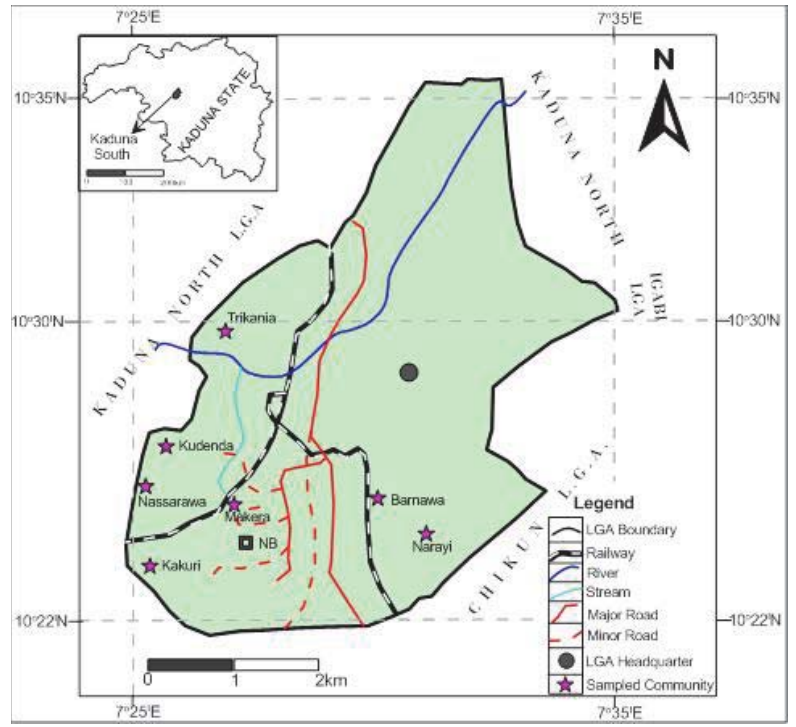

Figure 2: Map of Kaduna South L.G.A Showing the Sampled Communities and the Location of the Brewery Industry (Source: Kaduna South L.G.A Secretariat, Madera Kaduna)

Nine attribute variables each of social and economic impacts were considered in this work. Nine social attribute variables of social attribute variables of social impact of Nigerian Brewery in the study area considered in work are: (B1) Increase in the population of the communities in area (B2) Increase in crime rate and abnormal behavior due to beer (alcohol) consumption. (B3) Health problem due to alcoholism, (B4) Infrastructural development, (B5)Traffic accidents due to excessive consumption of alcohol (beer), (B6) House congestion in the area, (B7) Increase in beer parlors, bars and alcoholic consumption, (B8) Provision of recreation center for youths and children, and (B9) Support in education of the masses in the area by the company have been used to assess the impacts of Nigerian Brewery on the social life of the people of Kaduna South LGA. Again, to determine the economic impact of the brewery in the study area, nine economic attribute variables considered are: (C1) Employment opportunities (direct and indirect), (C2) Increase in cost of goods and services), (C3) Increase in cost of rent/accommodation,(C4) Increase in income for the masses, (C5) Increase in growth pole (establishment of other industries/firms in the area), (C6) Increase in revenue and income generation for the government of the state, (C7) Reduction in poverty, (C8) Increase in market size in the area, and (C9) Increase in trading activities in the area.

The checklist was designed on a Likert five- point response continuum scales where strongly positive impact was coded 5, positive impact 4, no impact 3, negative impact 2, and strongly negative impact 1 . Thus, each of these was accessed to determine the degree of impact of the NB PIc. Kaduna on the social environment of Kaduna South LGA. The quantification of the impacts into five categories enabled us to determine the degree to which each variable contributes positively or negatively as regards the operations of the Nigerian Brewery Industry in the study area.

The secondary data for this study were sourced from cognate literature, surveyed maps, published materials on environmental impact of brewery industry and unpublished academic project works, government agencies (Kaduna State Environmental Protection Agency-KEPA), and Kaduna South LGA information bulletins. Table 1 shows the summary of the number of questionnaires distributed and the number returned during the fieldwork. From the Table 1, 91.43\% of the total number of questionnaires was returned.

The analysis of the Nigerian Brewery PIc impact was based on the frequency values obtained from our checklist. This enabled us to obtain the mean scores, standard deviations and variances of the frequency counts of the response values whose sum total is 15 for each Nigerian Brewery impact attribute variable and dividing by 5 gives a mean of 3 . From the individual mean for each variable, any mean above 3 shows a high level of impact and below 3 shows a low level of impact. Thereafter, Principal Component Analysis (PCA) was used to isolate the most valuable socio-economic attribute variables related to Nigerian Brewery PIc impact and interpreted the results to portray / define broader areas for planning and actions by the shareholders in Nigerian Brewery in Kaduna South LGA. 
Table 1: Summary of Questionnaire Distribution Return during the Fieldwork

\begin{tabular}{|c|l|c|c|c|}
\hline $\mathbf{S} / \mathbf{N}$ & Areas & $\begin{array}{c}\text { Number Of Questionnaires (Checklist) } \\
\text { Submitted }\end{array}$ & $\begin{array}{c}\text { Number Of Questionnaires (Checklist) } \\
\text { Returned }\end{array}$ & Percentage (\%) \\
\hline 1 & Kakuri & 20 & 20 & 100 \\
\hline 2 & Nassarawa & 20 & 18 & 90 \\
\hline 3 & Trikania & 20 & 19 & 95 \\
\hline 4 & Kudenda & 20 & 17 & 85 \\
\hline 5 & Barnawa & 20 & 19 & 95 \\
\hline 6 & Narayi & 20 & 16 & 80 \\
\hline 7 & Makera & 20 & 19 & 95 \\
\hline & TOTAL & 140 & 128 & 91.43 \\
\hline
\end{tabular}

Source: Fieldwork, 2014

\section{Results and Discussions}

\subsection{The analysis of Frequency Distributions of the Social Impacts of the Brewery in the Area.}

sis presented in Table 2. From Table 2, it is observed that there is a high level of social impact of NB PIc Kaduna on the study area. For instance, variable B9 (Support in education of the masses in the area by the company), with a mean of 4.1 (mean > 3.0), a standard deviation of 1.3 , and a variance of 0.1 , recorded 53.9 percent under 'strongly agree' and 25.8 percent under "agree" totaling 79.7 percent for both. "Strongly disagree' scored 9.38percent, 'disagree' scored 7.8 percent and 'undecided scored 3.1 percent. Variable B8 (Provision of recreation centers for youths and children) recorded 46.9 percent for 'strongly agree' and 23.4 percent for 'agree' totaling 70.3 percent for both. The 'undecided', 'disagree' and 'strongly disagree' recorded 16.4 percent, 7.03 percent and 6.25 percent respectively with a mean of 4.0 (mean> 3.0), a standard deviation of 1.2 and a variance of 0.1 .

Only two variables recorded low level of impact on the area. Firstly, B3 (Health problem due to alcoholism) with a mean of 2.4 (mean < 3.0), standard deviation of 1.3 , and a variance of 0.3 , scored 30.1 percent under 'disagree' and 10.2 percent for 'strongly agree'. The second variable, B2 (Increase in crime rate and abnormal behaviour due to beer consumption (alcohol)) also recorded a mean of 2.8 (mean < 3.0), a standard deviation of 1.4 and a variances of 0.2 . 'Disagree' scored 35.2 percent, 'strongly agree' and 'strongly disagree' scored 15.6 percent and 14.8 percent respectively. Thus, Fig 3 depicts in nutshell, the frequency distribution of the social impact attribute variables. It is observed from Fig 3 that 7 social impact attribute variables were perceived with high impact by the households in the study area.

Table 2: Absolute and Relative Frequency Distribution of the Social Impacts of the NB PIc Kaduna in the study area

\begin{tabular}{|c|c|c|c|c|c|c|c|c|c|}
\hline $\begin{array}{c}\text { Variable } \\
\text { Code } \\
\end{array}$ & Variables Discription & $\begin{array}{l}\text { Strongly } \\
\text { agree }\end{array}$ & Agree & Undecided & Disagree & $\begin{array}{l}\text { Strongly } \\
\text { disagree }\end{array}$ & Mean & $\begin{array}{l}\text { Std. } \\
\text { Dev. }\end{array}$ & Variance \\
\hline & & 5 & 4 & 3 & 2 & 1 & $(\mathrm{x})$ & $(\mathrm{s})$ & \\
\hline B1 & $\begin{array}{l}\text { Increase in the populations of the } \\
\text { communities in the area }\end{array}$ & $40(31.3 \%)$ & $35(27.3 \%)$ & $14(10.9 \%)$ & $17(13.3 \%)$ & $22(17.2 \%)$ & 3.4 & 1.5 & 0.4 \\
\hline B2 & $\begin{array}{l}\text { Increase in crime rate and abnormal } \\
\text { behavior due to beer consumption } \\
\text { (alcohol) }\end{array}$ & $22(17.2 \%)$ & $19(14.8 \%)$ & $20(15.6 \%)$ & $45(35.2 \%)$ & $22(17.2 \%)$ & 2.8 & 1.4 & 0.2 \\
\hline B3 & Health problem due to alcoholism & $13(10.2 \%)$ & $15(11.7 \%)$ & $19(14.8 \%)$ & $50(30.1 \%)$ & $31(24.22)$ & 2.4 & 1.3 & 0.3 \\
\hline B4 & Infrastructural development & $49(38.3 \%)$ & $27(21.1 \%)$ & $29(22.7 \%)$ & $15(11.7 \%)$ & $8(6.25 \%)$ & 3.7 & 1.3 & 0.1 \\
\hline B5 & $\begin{array}{l}\text { Traffic accidents due to excessive } \\
\text { consumption of alcohol (beer) }\end{array}$ & $30(23.4 \%)$ & $15(11.7 \%)$ & $48(37.5 \%)$ & $28(21.9 \%)$ & $7(5.47 \%)$ & 3.3 & 1.2 & 0.3 \\
\hline $\mathrm{B} 6$ & House congestion in the area & $41(32.03 \%)$ & $14(10.9 \%)$ & $10(7.8 \%)$ & $38(29.7 \%)$ & $25(19.5 \%)$ & 3.1 & 1.6 & 0.3 \\
\hline B7 & $\begin{array}{l}\text { Increase in beer parlors, bars and } \\
\text { alcoholic consumption }\end{array}$ & $51(39.8 \%)$ & $31(24.2 \%)$ & $9(7.03 \%)$ & $27(21.1 \%)$ & $10(7.8 \%)$ & 3.7 & 1.4 & 0.2 \\
\hline B8 & $\begin{array}{l}\text { Provision of recreation center for youths } \\
\text { and children }\end{array}$ & $60(46.9 \%)$ & $30(23.4 \%)$ & $21(16.4 \%)$ & $9(7.03 \%)$ & $8(6.25 \%)$ & 4.0 & 1.2 & 0.1 \\
\hline B9 & $\begin{array}{l}\text { Support in education of the masses in the } \\
\text { area by the company }\end{array}$ & $69(53.9 \%)$ & $33(25.8 \%)$ & $4(3.13 \%)$ & $10(7.8 \%)$ & $12(9.38 \%)$ & 4.1 & 1.3 & 0.1 \\
\hline
\end{tabular}

Source: Fieldwork, 2014 


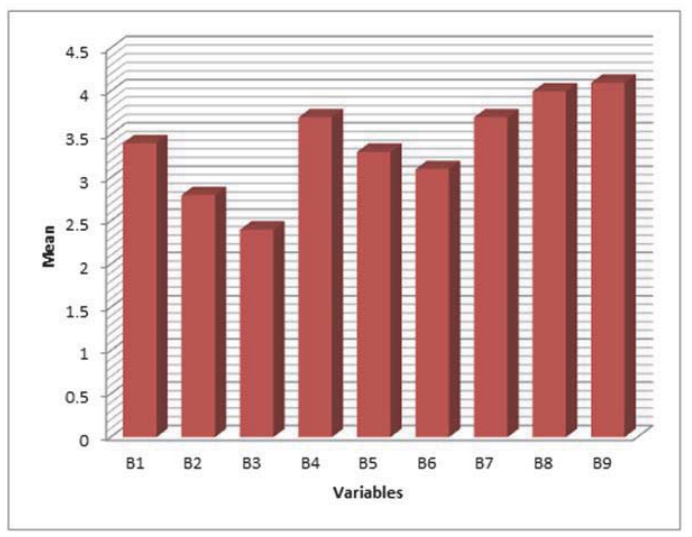

Figure 3: Frequency distribution of attribute variables of the social impacts of Nigerian Brewery in the area.

(Source: Fieldwork, 2014)

Only two attribute variables (B3 and B2) of social impact were perceived by the households in the area with low level impact. The conclusion from the analysis is that, generally households in Kaduna South LGA are satisfied with the social impact of Nigerian Brewery on the area

\subsection{Principal Component Analysis (PCA) of the Social Assessed Impacts for the Study Area}

The relationship between each variable for the social impact assessed was established by Pearson's correlation technique to know the strength of the correlations. A close observation of the correlation matrix (not shown in this paper), shows that all the variables are positively correlated with each other. And also, the variables are highly correlated with each other and may be difficult to explain its pattern because of the existence of some redundancies, thereby making factor analysis or the principal component analysis inevitable. To remove the effect of these strong inter-correlations between the variables, as well as include the contributions of the apparently redundant (weakly correlating) variables, PCA was employed to collapse the 9 variables of social impacts of Nigerian Brewery PIc in Kaduna South L.G.A. into a few orthogonal factors that could define broader areas for planning and action by the stakeholders in the management of Nigerian Brewery PIc in the study area. The results of the analysis of the varimax rotated components are presented in Table 3.

Table 3: Results of Varimax Rotated Principal Components Matrix for Social Assessed Impact of Nigerian Brewery in the Study Area

\begin{tabular}{|c|l|c|c|}
\hline \multirow{2}{*}{ VARIABLE Codes } & \multirow{2}{*}{ Variable Descriptions } & \multicolumn{2}{|c|}{ Components } \\
\cline { 3 - 4 } & & 1 & 2 \\
\hline B1 & Increase in the populations of the communities in the area & $.763^{*}$ & .610 \\
\hline B2 & Increase in crime rate and abnormal behavior due to beer consumption (alcohol) & .488 & $.838^{*}$ \\
\hline B3 & Health problem due to alcoholism & .382 & $.906^{*}$ \\
\hline B4 & Infrastructural development & $.791^{*}$ & .578 \\
\hline B5 & Traffic accidents due to excessive consumption of alcohol (beer) & .537 & $.822^{*}$ \\
\hline B6 & House congestion in the area & .586 & $.752^{*}$ \\
\hline B7 & Increase in beer parlors, bars and alcoholic consumption & $.801^{*}$ & .562 \\
\hline B8 & Provision of recreation centers for youths and children & $.867^{*}$ & .459 \\
\hline B9 & Support in education of the masses in the area by the Company & $.901^{*}$ & .349 \\
\hline Eigen values & & 4.43 & 4.12 \\
\hline \% of Explained variance & 49.21 & 45.76 \\
\hline Cumulative \% of Explained Variances & 49.21 & 94.97 \\
\hline
\end{tabular}

* Significant loadings exceeding \pm 0.70 .

Source: Fieldwork, 2014. 
The PCA has succeeded in reducing the 9 independent variables to two orthogonal or uncorrelated components which together account for $94.97 \% \%$ of the total variance within the variables. Thus, leaving only $5.03 \%$ of the total variance in the variables unexplained. The component loadings are exceptionally very high and above 0.800 in some cases.

Component I explains $49.21 \%$ of the total variance and have significant loadings on 5 variables with an eigenvalue of 4.43. The variables are namely B1 (increase in the population of the community), B4 (lead to infrastructural development), B7 (increase in beer parlors, bars and alcoholic consumption), B8 (provision of recreation centers for youth and children) and B9 (support in education of the masses in the area by the company). In the entire study area most especially in areas such as Kakuri, and Nassaarwa, there is an increase in the population of the community due to the presence of the brewery industry. There is also a development in infrastructure in terms of good roads, pipe borne water supply and electricity which were provided by the brewery industry. Apart from this, there is an increase in the number of bars and alcohol consumption arising from the consumption of the products and the services of the industry. The industry has also provided recreational centers such as seen in their support in sports like golf, lawn tennis etc. They have also supported the education of the masses by the providing of computer equipment for schools and the building of academic classrooms for learning. The underlying factor here is identified as Provision of Social Amenities.

Component II explains $45.76 \%$ of the total variance and has significant loadings on 4 variables with an Eigen value of 4.12. The variables are B2 (Increase in crime rate and abnormal behavior due to alcoholism), B3 (Health problems due to alcoholism), B5 (Traffic accidents due to excessive consumption of alcohol (beer) ) and B6 (House congestion in the area). It was discovered that there are certain traces of abnormal behaviors in the lives of the youths due to excess consumption of the products (alcoholic contents) of the brewery industry and thus when they are drunk, they tend to misbehave all along in the community contributing to nuisance in the community and increase in crime rates. This fact has led to many health complications to such persons as seen in the case of most of them having health challenges such as liver cirrhosis, brain distortion, injuries sustained in automobile accident and light headedness among others. It also led to increase in causality rate due to robbery and other related crimes. Some still benefit from this and thus it has improved their standard of living by the provision of health aides to hospitals by the industry. This issue has also brought about house congestion in the area as many tend to relocate from other places to stay within the reach of the industry as well as to be close and benefit more from it. Thus, the underlying factor in the case is identified as insecurity of life and property.

\subsection{The analysis of Frequency Distributions of the Economic Impacts of the Brewery in the Area.}

The statistical frequency distribution of respondents' perception of the attribute variables of economic impact of Nigerian Brewery PIc on Kaduna South LGA is presented in Table 4. From Table 4, it is observed that 8 attribute variables of economic impact of the brewery were perceived by the households to have high impact in the study area. For instance, variable C1 (Employment opportunities (direct and indirect)) recorded 70.3 percent under 'Strongly Agree', 24.2 percent under 'Agree' and Zero percent under 'Undecided'. 'Disagree' and 'Strongly Disagree' recorded 3.13 percent and 2.34 percent respectively with a mean of 4.6 (mean > 3.0), a standard deviation of 0.9 and a variance of 0.1 . Variable C6 (Increase in revenue and income generation of the governments) scored 43.8 percent under 'Strongly Agree', 35.9 percent under 'agree' both totaling 79.7 percent. 'Undecided', 'Disagree' and 'Strongly Disagree' scored 14.8 percent, 3.13 percent and 2.34 percent respectively with a mean of 4.2 (mean> 3.0), a standard deviation of 0.9 and a variance of 0.1 . Only variable $\mathrm{C} 7$ (reduction in poverty rate) was perceived by the households to have low level impact on the study area. It scored a mean of 2.3 (mean < 3.0), a standard deviation of 1.3 and a variance of 0.5 . 'Disagree' is 38.3 percent, 'strongly disagree' is 32.8 percent and 'Strongly Agree' is 11.7 percent, while 'Agree' and 'Undecided' are 10.2 percent and 7.03 percent respectively.

In summary, the frequency distribution of the attribute variables of economic impact of Nigerian Brewery presented in Fig 4 shows that out of the nine (9) attribute variables of the economic impact on the study area, eight (8) variables were perceived by the households to have high impact, while only one was perceived to have low impact by the households in the area. The conclusion from the analysis is that, generally the households in the Kaduna South LGA are satisfied with the economic impact of Nigerian Brewery PIc on the area. 
Table 4: Frequency Distribution of the Economic Impacts of the NB PIc Kaduna in the Study Area

\begin{tabular}{|c|l|c|c|c|c|c|c|c|c|}
\hline $\begin{array}{c}\text { Variable } \\
\text { Code }\end{array}$ & Variables Description & $\begin{array}{c}\text { Strongly } \\
\text { Agree }\end{array}$ & Agree & Undecided & Disagree & $\begin{array}{c}\text { Strongly } \\
\text { Disagree }\end{array}$ & Mean & $\begin{array}{c}\text { STD. } \\
\text { DEV. }\end{array}$ & Variance \\
\hline & & 5 & 4 & 3 & 2 & 1 & $(\mathrm{x})$ & $(\mathrm{s})$ & \\
\hline C1 & Employment opportunities (direct and indirect) & $90(70.3 \%)$ & $31(24.2 \%)$ & - & $4(3.13 \%)$ & $3(2.34 \%)$ & 4.6 & 0.9 & 0.1 \\
\hline C2 & Increase in cost of goods and services & $41(32.0 \%)$ & $15(11.7 \%)$ & $20(15.6 \%)$ & $50(30.1 \%)$ & $2(1.56 \%)$ & 3.3 & 1.3 & 0.3 \\
\hline C3 & Increase in cost of rent/accommodation & $31(24.2 \%)$ & $31(24.2 \%)$ & $30(23.4 \%)$ & $21(16.4 \%)$ & $15(11.7 \%)$ & 3.3 & 1.3 & 0.3 \\
\hline C4 & Increase in income for the masses & $20(15.6 \%)$ & $14(10.9 \%)$ & $56(43.8 \%)$ & $39(28.9 \%)$ & $1(0.78 \%)$ & 3.1 & 1.0 & 0.4 \\
\hline C5 & $\begin{array}{l}\text { Increase in growth pole (establishment of } \\
\text { other industries/firms in the area) }\end{array}$ & $14(10.9 \%)$ & $15(11.7 \%)$ & $34(26.6 \%)$ & $50(30.1 \%)$ & $15(11.7 \%)$ & 3.8 & 1.1 & 0.2 \\
\hline C6 & $\begin{array}{l}\text { Increase in revenue and income generation } \\
\text { for the government of the state }\end{array}$ & $56(43.8 \%)$ & $46(35.9 \%)$ & $19(14.8 \%)$ & $4(3.13 \%)$ & $3(2.34 \%)$ & 4.2 & 0.9 & 0.1 \\
\hline C7 & Reduction in poverty & $15(11.7 \%)$ & $13(10.2 \%)$ & $9(7.03 \%)$ & $49(38.3 \%)$ & $42(32.8 \%)$ & 2.3 & 1.3 & 0.5 \\
\hline C8 & Increase in market size in the area & $4(3.13 \%)$ & $49(38.3 \%)$ & $30(23.4 \%)$ & $44(34.4 \%)$ & $1(0.78 \%)$ & 3.1 & 0.9 & 0.4 \\
\hline C9 & Increase in trading activities in the area & $28(21.9 \%)$ & $42(32.8 \%)$ & $32(25 \%)$ & $26(20.3 \%)$ & - & 3.7 & 1.1 & 0.4 \\
\hline
\end{tabular}

Source: Fieldwork, 2014

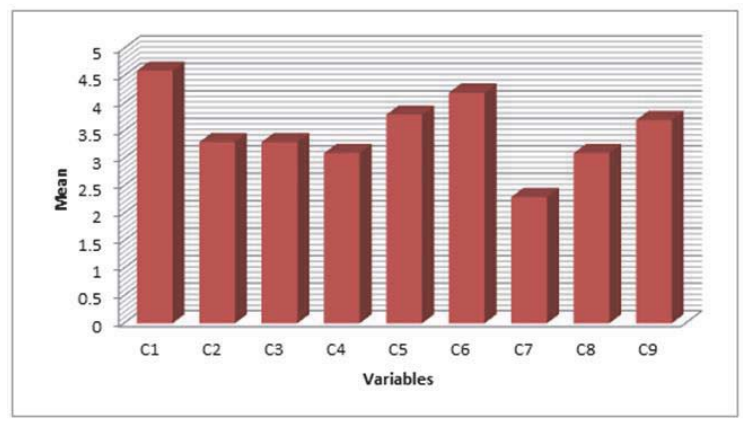

Figure 4: Frequency distribution of attribute variables of the economic impact of Nigerian Brewery on the area.

Source: Fieldwork, 2014

\subsection{Principal Component Analysis (PCA) of the Economic Assessed Impacts for the Study Area}

The relationship between each variable for the economic impact assessed was established by Pearson's Correlation Technique. A close observation of the correlation matrix (not shown in this paper) shows that all the variables are positively correlated with each other. The variables are also highly correlated with each other and may be difficult to explain its pattern because of the existence of some redundancies, thereby making the Principal Component Analysis inevitable. To remove the effect of these strong inter-correlations between the variables as well as include the contributions of the apparently redundant (weakly correlating) variables, PCA technique was employed to collapse the 9 attribute variables of economic impact of Nigerian Brewery into few orthogonal factors that could define broader areas for interventions by the shareholders in the brewery to enhance the economic life of the people in the area. The results of the analysis of the varimax rotated components are presented in Table 5. The PCA has succeeded in reducing the 9 independent variables to three orthogonal or uncorrelated components which together account for $95.53 \%$ of the total variance within the variables. Thus, leaving only $4.47 \%$ of the total variance in the variables unexplained.

Table 5: Results of Varimax Rotated Principal Components Matrix for Economic Assessed Impact of Nigeria Brewery in the Study Area.

\begin{tabular}{|c|l|c|c|c|}
\hline \multirow{2}{*}{ Variable Codes } & \multirow{2}{*}{ Variable Description } & \multicolumn{2}{|c|}{ Components } \\
\cline { 3 - 5 } & & 1 & 2 & 3 \\
\hline C1 & Employment opportunities (direct and indirect), & .245 & .192 & $.941^{*}$ \\
\hline C2 & Increase in cost of goods and services & .574 & $.740^{\star}$ & .296 \\
\hline C3 & Increase in cost of rent/accommodation, & .651 & .523 & .505 \\
\hline
\end{tabular}




\begin{tabular}{|c|c|c|c|c|}
\hline $\mathrm{C} 4$ & Increase in income for the masses & $.865^{*}$ & 322 & 334 \\
\hline $\mathrm{C} 5$ & Increase in growth pole (establishment of other industries/firms in the area & $.797^{\star}$ & .442 & .320 \\
\hline C6 & Increase in revenue and income generation for the government of the state, & .371 & .547 & $.724^{\star}$ \\
\hline $\mathrm{C7}$ & Reduction in poverty & $.894^{*}$ & .364 & .209 \\
\hline $\mathrm{C} 8$ & Increase in market size in the area & .532 & $.726^{*}$ & .363 \\
\hline $\mathrm{C9}$ & Increase in trade (within and without) in the area. & .677 & .531 & .430 \\
\hline \multicolumn{2}{|c|}{ Eigen values } & 3.87 & 2.39 & 2.33 \\
\hline \multicolumn{2}{|c|}{$\%$ of Explained variance } & 43.04 & 26.65 & 25.83 \\
\hline \multicolumn{2}{|c|}{ Cumulative $\%$ of Explained Variance } & 43.04 & 69.65 & 95.53 \\
\hline
\end{tabular}

Source: Fieldwork,2014

Component I explain $43.04 \%$ of the total variance and have significant loadings on 3 variables with an Eigen value of 3.87. The variables are C4 (increase in income for the masses), C5 (increase in growth pole) and C7 (reduction in poverty). It is observed that there is an increase in the income of the masses created by the NB Plc Kaduna in the study area by means of being gainfully employed. This has also brought about an increase in growth pole (establishment of other industries/firms in the area) because the presence of one industry in a place gives rise to another which has added to income generation and has helped reduce poverty rate although, on a minimal level. The underlying factor in this case is identified as increase in standard of living.

Component II explains $26.65 \%$ of the total variance and has significant loadings on 2 variables with an eigenvalue of 2.39. The variables are C2 (increase in cost of goods and services) and C8 (increase in market size in the area). It was observed that there is an increase in the cost of goods and services within the study area as created by the existence of the brewery industry which has brought about an increase in market size in the area and as a result of this, there is an increase in economic services going on in the area such as the sales of goods, products and services which has in turn increased market size in the area. Thus, the underlying factor in this case is identified as high cost of living and increase in commercial activities.

Component III explains $25.83 \%$ of the total variance and has significant loadings on 2 variables with an Eigen value of 2.33. The variables are C1 (employment opportunities) and C6 (increase in revenue and income generation for the government of the state). The establishment of any industry is thus to create employment either directly or indirectly for the populace within the area. As such, the NB PIc Kaduna has succeeded in creating such direct employment to people and also an indirect one such as seen in the cases of outlet shops and depots which engages in wholesale and retail of the brewery products. Also, the increase in revenue and income generation to the government of the state is not left out as it has always contributed its own quarter to this effect by its payment of tax to the government. Thus, the underlying factor in this case is identified as increase in income generations.

\section{Conclusions and Recommendations}

The Nigerian Brewery Industry in Kaduna South LGA, Kaduna State is undoubtedly a great investment to the entire area and the state at large. The study investigated the socio-economic impacts of Nigerian Brewery in Kaduna South Local Government Area (LGA) of Kaduna State. The contribution of this study is the identification of positive and negative impacts of Nigerian Brewery Industry in the study area. The underlying impact factors identified are provision of social amenities insecurity, increase in standard of living, high cost of living, increase in commercial activities, and increase in income generations. The study thus provides direction for governments, Nigerian Brewery and the communities in Kaduna South Local Government Area for assessing the positive impacts and the level of reduction of negative impacts of the brewery on the study area.

Based on the findings, we make the following recommendations. To solve the problems of beer consumption related crimes and aggressive behaviour that are threatening the security of lives and property in the study area, the governments and the people of the Kaduna South LGA have to undertake educational programmes relating to beer consumption to increase the peoples understanding of health issues relating to beer consumption and to raise the awareness of the social and legal implications of excessive beer consumption to the individual and the impact it has on other people. Governments and the people of the study area should also identify ways for effecting changes regarding the sale or promotion of beer where these can be shown to have a negative impact on the health and the well-being of the people in the area. 
To enhance the purchasing power of the Kaduna South LGA people to meet the demand of high cost of living in the area triggered off by the establishment of the Nigerian Brewery in the area, there should be more employment opportunities for the people of Kaduna South LGA to better their socio-economic life. To make this possible, there should be a special provision backed by law for the provision of employment by the Nigerian Brewery Plc to the people from the Kaduna South LGA. Furthermore, income generating projects should be established in the area by the Nigerian Brewery Plc and the government. To avoid beer consumption related accidents in the area, drinking and driving by the people in the area should be seriously discouraged to avoid beer consumption related accidents through drinking-driving, mass media advertising, environment impact prevention measures, road safety education and continuing road safety law enforcement. The Nigerian Brewery PIc should embark on more community development projects to be prioritized by the people of the Kaduna South LGA yearly with emphasis given to the projects such as hospitals, potable water, schools, roads, housing estate etc that have direct bearing on the socio-economic lives of the people in the area.

\section{Refrences}

Aboh, H. O. (2009): Assessment of the Aquifers in some selected villages in Chikun Local Government Area, Kaduna State. Nigeria Journal of Science World, Vol. 4, 2, pp. 37- 42

Ahmed, I. S (2014): Personal Communication

Babor, T. (2001): Alcohol not Ordinary Commodity, Research and Public Policy, Oxford University Press.

Babor, T. (2008): "The Cost of Alcohol, Tobacco and Illicit Drugs in the Social and Economic Lifestyle in Canada". Addition' 93; 7, pp 983-998.

Banji, O. (2000): Where to Locate your Business: Factors to consider. Helium Inc. Simon Fraser University.

Best, M. (2003): The New Comparative Advantage. The Renewal of American Industry, Oxford: Oxford University Press.

Environmental Audit Report on Nigerian Brewery PIc Kaduna, 2010.

FAO Source (2003): 2000-2002 World Beer Production. BIOS Int. 8 (2), 47 e50.

Freeman, C., and Soete, L. (2003): The Economic of Industrial Innovation, Printer Publisher, London.

Furnivall, L. (2009): The Perfect Storm: A Review of the Influence of Guinness Breweries PC in Africa. New York: W.W. Norton Co.

Ilori, M. O., Adeniyi, A. A., Oyewale, A. A., Sanni, S. A., and Irefin, I. A., (2002): "Developing a Manufacturing-Based Economy in Nigeria through Science and Technology". Technovation Vol. 22, pp 51-60.

Odo, A. (2010): Effect of Corrosive Environment on the Strength of Concrete A Case Study of the Effluents from Nigerian Brewery Kaduna. An Unpublished OND Project, Department of Civil Engineering, Kaduna Polytechnic, Kaduna.

Okoye, C. (2008): Safety Requirement and Accident Prevention in Industries. An Unpublished HND Project, Department of Environmental Science Kaduna Polytechnic, Kaduna.

Okpala, I. (1999): Enhancing Environmental Protection in Nigeria through Environmental Education. The International Seminar on the Petroleum Industry and the Nigeria Environment, New York USA.

Olajire, A. A. (2012): "The brewing industry and environmental challenges", Journal of Cleaner Production2012Olajire.03.003, doi:10.1016/j.jclepro. 